\title{
Do Foreign Workers' Positive Contributions to GDP Outweigh the Negative Effect of Their Outward Remittances on GDP? A Case Study of Saudi Arabia
}

\author{
Fayq Al Akayleh \\ College of Business Administration, Al Yamamah University, Saudi Arabia \\ *Corresponding Author: bsbann@gmail.com
}

Copyright $\bigcirc 2016$ by authors, all rights reserved. Authors agree that this article remains permanently open access under the terms of the Creative Commons Attribution License 4.0 International License

\begin{abstract}
This paper examines the effects of foreign workers' outward remittances on the economic activity of a country that hosts foreign labor by developing a new econometric technique to measure the effect of workers' outward remittances on gross domestic product of the world's largest oil producer, namely Saudi Arabia. Results indicate that outward remittances have negative and significant effects on all types of aggregate demand. The total effect of outward remittances on GDP is, then, negative. The study findings prove that the net effect of non-Saudi workers on GDP is positive for the Saudi GDP.
\end{abstract}

Keywords Regression Estimation, International Migration, Remittances, Production and GDP, Government Policy and Regulations, Saudi Arabia

\section{Introduction}

This paper addresses the impact of workers' outward remittances on economic activity in the world's largest oil producer, namely Saudi Arabia. The key analysis in this paper is based on secondary data obtained from national and international resources. This research is motivated by a concern among policymakers that outward remittances, or monies earned by foreign nationals and sent to their home nation, absorb a large share of the country's GDP. More specifically, the study estimates the impact of outward remittances on consumption, investment, government expenditure, exports, and imports.

The primary challenge of this study was to assess the effect of outward remittances on the economic activity with GDP as the most accurate proxy for economic activity. This challenge arises from the difficulty of isolating the effect of outward remittances from the effects of other variables that impact economic activity in one way or another. The task before the author of this paper then was how to estimate the effect on GDP that results from outward remittances only.

Sections II and III state the objectives of the study and provide a review of the relevant literature. Section IV outlines Saudi Arabia's government policies relative to the labor market. The effect of outward remittances on the current account side of the Saudi balance of payments is analyzed in Section V. The estimation method for the effect of outward remittances on economic activity and the net effect of non-Saudi workers' outward remittances on Saudi GDP is the subject of Sections VI and VII. Section VIII concludes.

\section{Importance and Objectives of the Study}

In all debates about the effect of outward remittances on Saudi Arabia, the only measure that has been taken as evidence of the clear negative impact of outward remittances is the amount of these remittances themselves. Various reports have warned, now and then, of the severity of increasing outward remittances without showing robust quantitative measures for these effects on the Saudi economy.

Therefore, this paper first and foremost, introduces a new quantitative and econometrical measures by which to examine the impact of foreign labor outward remittances on the economic activity in Saudi Arabia. Three secondary objectives were (1) to study the development of outward workers' remittances in KSA, (2) to discuss analytically the role of government policies in the foreign labor market; and (3) to show the effect of such remittances on the current account balance.

\section{Review of the Literature}

In studying remittance effects, the vast majority of 
previous studies focused on merely comparing GDP including remittances with GDP excluding remittances [1]. Others have analyzed the effect of inward remittances on economic growth $[2,3]$ yet these studies did not consider the net effect of remittances because of ignorance about the outward remittances effect. Productivity and the contribution of immigrants to the economy of hosting countries showed direct and indirect effects [4] without considering the effects of brain drain on the economy of the home country [5]. As an attempt to overcome many of the above-stated research shortcomings, some relatively recent studies have tried to examine the net effect of remittances in a particular country [6].

When studying the effect of remittances (both inward and outward), most of published works have not considered the long-run effect of labor migration, particularly on the home country of those workers. After home countries invest considerable long-run money from the public budget to the development of human capital of their citizens, developed countries leave them after they skim off their best and brightest for which developing countries should be compensated $[7,8,9,10,11]$.

Saudi Arabia is the world's second remittance-sending country. The outward remittances from Saudi Arabia exceeded \$35.9 billion US in 2014 [12]. Outward remittances in Saudi Arabia have been addressed by few studies and are considered a drain from private savings in Saudi Arabia [13]. Factors that affect remittances also are a very important dimension in analyzing economic growth and the effects on the balance of payments [1], yet this dimension is beyond the scope of this paper.

The literature on the subject also includes several studies on governmental policies with respect to nationalization of jobs and wage inequality [14] or regarding the remittances and family ties related factors [15]. The literature also has focused on analysis of the trend of migration and workers' remittances across regions of various countries, such as migration from east to west, from north to south, from the Arab world to the West, and from low-income Arab countries to high-income Arab countries [16].

\section{Government Policies on Labor Market and Employment}

The Saudi Arabian Central Department of Statistics and Information [17] estimated that the population of Saudi Arabia in mid-2014 increased by $2.6 \%$ to 30.8 million (compared to 30 million in 2013) such that the Saudis constituted $67.3 \%$ of the total population; the total female population was $44 \%$. Data from the Ministry of Civil Service [18] showed that Saudi employees in the Saudi public sector were $94.2 \%$ of the total employment for this sector. Saudi employment of women increased in 2014 by $4.3 \%$ over 2013 ; employment of non-Saudi women decreased by $4.6 \%$ for the same period in the public sector.

The Saudi government continues its efforts to nationalize jobs in both the public and private sectors. The data note above showed significant advancement toward the objective of job nationalization in the public sector. The private sector also contributed to the job nationalization objective orchestrated by the Ministry of Labor using various programs, such as the Hafiz Program (to support job seekers), the Nitaqat Program (to stimulate private sector to nationalize posts), and the Taqat Program (to provide various employment channels to help the private sector employ qualified Saudis from various segments of the job-seeking market). After more than two years of implementing these policies, the number of Saudi male and female workers in the private sector increased in 2014 compared to that in 2013. The increase in the number of Saudi male workers in 2014 compared to $2013(6.4 \%)$ was greater than that of non-Saudi male workers $(3.1 \%)$, yet the increase in the number of Saudi women workers $(3.6 \%)$ was lower than that of non-Saudi women workers (5.2\%) in the private sector in 2014 .

The success of these policies, however, depends upon the effectiveness of policy implementation. Although these policies were associated with employment of a large number of Saudi job seekers in the private sector, some of these programs may be counterproductive, particularly Nitaqat, because such programs may lead to financial losses if employed Saudis under these programs lack willingness to work productively or lack the skills required to perform certain jobs, which may put the country under the risk of hidden unemployment [19].

The implications of governmental policies for unemployment in Saudi Arabia include a slight decline in the unemployment rate among Saudis from 12\% in 2013 to $11.8 \%$ in 2014 . The breakdown of this unemployment rate indicates that unemployment among Saudi women decreased from $34.8 \%$ in 2013 to $33.3 \%$ in 2014 and that unemployment among Saudi males decreased slightly from $6.3 \%$ in 2013 to $6.0 \%$ in 2014 [12].

\section{The Effect of Workers' Outward Remittances on the Current Account}

The Saudi current account balance (CA) exhibited a persistent surplus. The oil boom in 2002-2008 had a positive impact on all of the economy's sectors, including a remarkable improvement in the CA balance, as shown in Figure 1. 


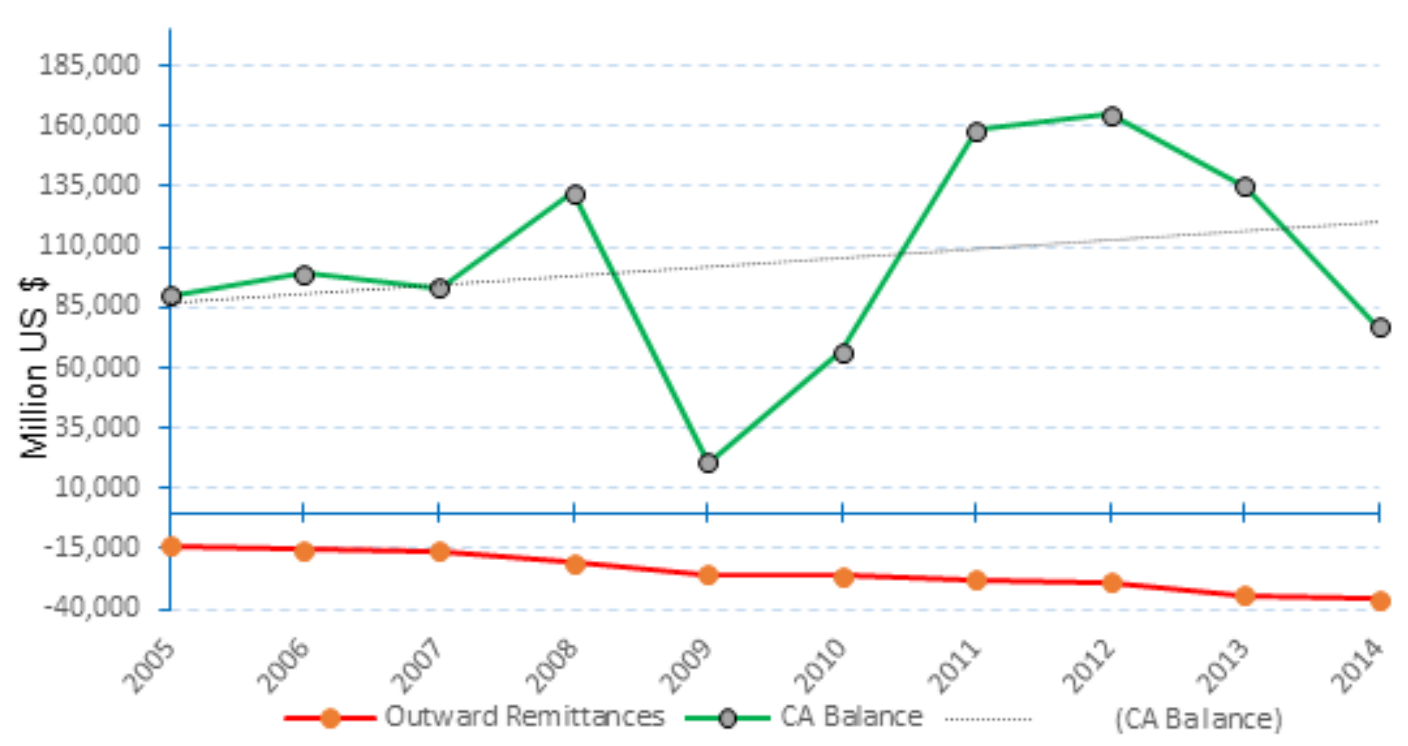

Source: Data were collected from Saudi Arabian Monetray Agency, Yearly Statistics, 2015

Figure 1. Workers' Outward Remittances and The Current Account Balance

The world economic and financial crisis of late 2007 that hit the U.S. economy and spread all over the world affected the CA balance in Saudi Arabia, which even so remained in surplus. The CA balance dropped from $\$ 132.3$ billion US in 2008 to $\$ 21.0$ billion US in 2009 (a drop of $530 \%$ ), which is attributed mainly to the dramatic drop in the trade balance from $\$ 146.2$ billion US in 2008 to a low of $\$ 40$ billion US in 2009; meanwhile workers' outward remittances increased from $\$ 20.9$ billion US in 2008 to $\$ 25.7$ billion US in 2009 (see Figure 1). From 2009 to 2012, the CA improved remarkably, exceeding the 2008 figures. The decrease in the world aggregate demand dropped the demand for oil.

This drop on demand for oil and the resulting decrease in trade surplus were associated with a remarkable increase in workers' outward remittances and resulted in a serious deterioration of the Saudi CA balance in 2013 and 2014. Workers' outward remittances have been persistently increasing over time.

\section{Workers' Outward Remittances and Economic Activity}

This section discusses the channels through which outward remittances may affect the gross domestic product (GDP). As stated previously, Saudi Arabia is the world's second largest remittance-sending country. In 2013, the country sent remittances totaling $\$ 34.1$ billion US, or $4.6 \%$ of the Saudi GDP. Clearly, workers' outward remittances are a drain on the national income stream (or from private savings). Therefore, it is very important for policymakers and researchers to identify the main channels through which outward remittances affect income (or GDP). In other words, what is the impact of workers' outward remittances on overall economic activity? This question can be answered by analyzing and examining the effect of outward remittances on each component of the GDP, as follows:

\subsection{Consumption Demand}

In theory, workers' outward remittances may negatively affect economic activity because of the negative effect on the private consumption channel because of the drains of such remittances on the private savings in the hosting country (i.e., Saudi Arabia in this study). If foreign laborers' consumption in Saudi Arabia is concentrated on imported goods and services, this situation may lead to an improvement in the Saudi trade balance; however, if consumption by non-Saudis is concentrated on domestically produced goods in Saudi Arabia, the effect will be a twofold negative effect in which the first negative effect is presented by the outward flows of income, which deteriorates the current account balance, and the second effect is the decline in consumption demand and hence lower GDP in Saudi Arabia from the multiplier effect.

Emigrants from a lower income country to a higher income one often settle with their families in the host country, and their consumption expenditure is then paid in the host country. In this case, emigrants clearly contribute to consumption expenditure in the host country. Therefore, all foreign workers working in Saudi Arabia contribute to consumption demand there.

\subsection{Investment Demand}

Investment demand is the second type of aggregate demand that is affected by outward remittances with a dual role. The first negative effect of outward remittances is the decline in financial resources required to finance investments as a result of the drains from private savings when outward remittances occur. Investment demand is also subject to a decrease as a consequence of increasing outward remittances because income outflow will reduce the consumption 
demand, as explained above, in the host country. Decreasing consumption levels prompt domestic investors in the host country to rethink their investment plans and to question "for whom should we produce?" In other words, the second negative role of outward remittances in investment is from the possible decrease in consumption that discourages investors to implement ambitious plans. However, this possibility of falling consumption as a result of increasing outward remittances depends on the foreign laborers' marginal propensity to consume in the host country.

For Saudi Arabia, investment by foreigners is gradually allowed under certain regulations, which may reduce the foreign laborer's marginal propensity to remit. In this case, these laborers will prefer to invest in the host country (i.e., Saudi Arabia) in the light of high consumption demand, which may encourage them to utilize the higher prices and the high marginal propensity to consume in Saudi Arabia.

\subsection{Government Demand}

It is expected, in theory, that there is a negative association between outward remittances and government expenditures; the greater the amount of money remitted out of the country, the lower the ability of the host country's government to spend on the national economy and vice-versa. The magnitude of this negative effect of outward remittances on government demand, however, depends mainly on two factors: (1) the amount of public salaries/wages paid by Saudi government to foreign workers, and (2) the non-Saudi laborers' marginal propensity to remit money outside Saudi Arabia.

\subsection{Net Trade}

The well-known trade balance is defined as the value of domestic exports minus the value of imports over a certain period of time. If non-Saudi workers inside of the Saudi economy tend to consume Saudi-produced goods and services, then Saudi total production will increase, resulting in more exports/less imports, which, in turn, will improve the trade balance in Saudi Arabia. In such a case, higher remittances will deteriorate the Saudi trade balance and vice versa. If, however, non-Saudi laborers prefer to consume imported goods and services inside the Saudi economy, then the Saudi trade balance will deteriorate. In this case, larger remittances will improve the Saudi trade balance despite the negative effect of these remittances on the current transfers in the balance of payments of Saudi Arabia. Does the positive effect of remittances on trade balance outweigh their negative effect on the current transfers of the balance of payments? The answer is beyond the scope of this paper and left to other researchers to answer it.

\section{Methodology}

To achieve the main objective of the study, we measured the effect of outward remittances on each type of aggregate demand types and then on aggregate demand (GDP) as a whole. The expected effect of outward remittances is then compared with the positive effect of foreign labor's contribution to GDP.

For simplicity, suppose Y stands for GDP. The total remittance effect is then the sum of its effects on consumption demand (C), investment demand (I), government demand $(\mathrm{G})$, export demand $(\mathrm{X})$, and imports (M). Rewriting the effect statement with $\mathrm{t}$ standing for time period (or a year), we get the following familiar aggregate demand equation:

$$
\mathrm{Y}_{\mathrm{t}}=\mathrm{C}_{\mathrm{t}}+\mathrm{I}_{\mathrm{t}}+\mathrm{G}_{\mathrm{t}}+\mathrm{X}_{\mathrm{t}}-\mathrm{M}_{\mathrm{t}}
$$

The method used the following main steps:

STEP I: Collection of data for all variables stated in equation (1) and on all variables inserted into equations (2), (3), (4), (5), and (6) for the study period 1980-2014. ${ }^{1}$ The objective of this time period was that it includes various business cycles of the Saudi economy, such as the recession of 1982-1987, the recovery of 1988-1992, the sluggish period of 1993-1996, the expansionary period of 1997-2007, the world recession of 2007-2009, and the world contractionary period of 2010-2014. This study period also considers the institutional changes in Saudi Arabian economy, particularly pre-accession and post-accession for WTO membership.

Data were collected from reliable national resources such as the Saudi Central Department of Statistics and Information (CDSI), Saudi Arabian Monetary Agency (SAMA), Ministry of Labor, and the Ministry of Economy and Planning. In few cases, data were collected from United Nations Conference on Trade and Development [20]. The money values of all relevant variables were in US dollars.

STEP II: Examination of the effect of non-Saudi workers' outward remittances on each component of GDP. That is, in this step, the study examined the impact of non-Saudi workers' outward remittances (Rn) separately on C, I, G, X, and M. This step implies that for each of the above-mentioned GDP components, the outward remittances effect was estimated using a multiple regression model by adjusting for the initial level of each component and real oil prices, as long as the Saudi Arabian economy is an oil-driven economy. The inclusion of oil prices and initial levels of each dependent variable is essential to avoid the econometric problem of misspecification [21,22]. Thus, in this stage the following set of regression equations was estimated and the parameters were determined:

$$
\begin{aligned}
& \mathrm{C}_{\mathrm{t}}=\alpha_{0}+\alpha_{1} \mathrm{C}_{\mathrm{t}-1}+\alpha_{2} \mathrm{R}_{\mathrm{nt}}+\alpha_{3} \mathrm{O}_{\mathrm{pt}}+\mathrm{U}_{1 \mathrm{t}} \\
& \mathrm{I}_{\mathrm{t}}=\beta_{0}+\beta_{1} \mathrm{I}_{\mathrm{t}-1}+\beta_{2} \mathrm{R}_{\mathrm{nt}}+\beta_{3} \mathrm{O}_{\mathrm{pt}}+\mathrm{U}_{2 \mathrm{t}} \\
& \mathrm{G}_{\mathrm{t}}=\gamma_{0}+\gamma_{1} \mathrm{G}_{\mathrm{t}-1}+\gamma_{2} \mathrm{R}_{\mathrm{nt}}+\gamma_{3} \mathrm{O}_{\mathrm{pt}}+\mathrm{U}_{3 \mathrm{t}} \\
& \mathrm{X}_{\mathrm{t}}=\delta_{0}+\delta_{1} \mathrm{X}_{\mathrm{t}-1}+\delta_{2} \mathrm{R}_{\mathrm{nt}}+\delta_{3} \mathrm{O}_{\mathrm{pt}}+\mathrm{U}_{4 \mathrm{t}}
\end{aligned}
$$

1 Secondary data table for GDP and its components selected as a time series sample in this study are not shown in this script because space constraints but can be provided upon request. 


$$
\mathrm{M}_{\mathrm{t}}=\Omega_{0}+\Omega_{1} \mathrm{M}_{\mathrm{t}-1}+\Omega_{2} \mathrm{R}_{\mathrm{nt}}+\Omega_{3} \mathrm{O}_{\mathrm{pt}}+\mathrm{U}_{5 \mathrm{t}}
$$

where $\alpha, \beta, \gamma \delta$, and $\Omega$ are regression coefficients for private consumption, investment, government expenditures, exports, and imports, respectively. $\mathrm{R}_{\mathrm{nt}}$ and $\mathrm{O}_{\mathrm{pt}}$ are non-Saudi workers' outward remittances and real oil prices over time. $U_{t}$ stands for stochastic term.

Regression results of the above set of equations are shown in Appendix 1 and are discussed in next section.

STEP III: After obtaining the regression estimates for the statistics $\alpha, \beta, \gamma \delta$, and $\Omega$, the next step was to extract the values of GDP components that are explained only by the non-Saudi workers' outward remittances. In other words, the effect of non-Saudi workers' outward remittances on C, I, G, $\mathrm{X}$, and $\mathrm{M}$ were estimated in money values, which was calculated using the following formulas:

$$
\begin{gathered}
\mathrm{C}_{\mathrm{t}}=-1.05 \mathrm{R}_{\mathrm{nt}} \\
\mathrm{I}_{\mathrm{t}}=-1.31 \mathrm{R}_{\mathrm{nt}} \\
\mathrm{G}_{\mathrm{t}}=-0.65 \mathrm{R}_{\mathrm{nt}} \\
\mathrm{X}_{\mathrm{t}}=-5.40 \mathrm{R}_{\mathrm{nt}} \\
\mathrm{M}_{\mathrm{t}}=-1.39 \mathrm{R}_{\mathrm{nt}}
\end{gathered}
$$

The above equations measure, in money value, the decrease/increase in Saudi GDP components $\left(C^{*}, I^{*}, G^{*}, X^{*}\right.$, $\left.\mathrm{M}^{*}\right)$ only as a result of the effect of non-Saudi workers' outward remittances. That is, applying the above set of equations (7), (8), (9), (10), and (11), we computed the predicted values of the GDP components that are only a result of outward remittances. Appendix 2 shows the predicted (estimated) decline/increase in each of the GDP components over the study period. These results are analyzed in the next section.

STEP IV: Summing up the expected decline in GDP components (as a result of outward remittances) to indicate the total decline in GDP as a result of non-Saudi workers' outward remittances.

GDP* denotes the total effect of non-Saudi workers' outward remittances on the Saudi GDP, or the total decline in GDP as a result of increasing non-Saudi workers' outward remittances such that

$$
\mathrm{GDP}_{\mathrm{t}}=\sum_{i=1}^{n}\left(N_{i t}\right)=\mathrm{C}_{\mathrm{t}}^{*}+\mathrm{I}_{\mathrm{t}}^{*}+\mathrm{G}_{\mathrm{t}}^{*}+\mathrm{X}_{\mathrm{t}}^{*}-\mathrm{M}_{\mathrm{t}}^{*}
$$

where $\mathrm{N}$ is the negative effect of outward remittances on GDP, $i=1,2,3,4,5$, and $\mathrm{t}$ stands for the time period (a year).

The result of equation (12) for the entire study period is shown in column (1) of Appendix 3 and is discussed in the next section.

STEP V: This step attempts to answer the question, Does the positive effect of non-Saudi workers' contribution to GDP outweigh the negative effect of their outward remittances?

To answer this question, we compared the percentage contribution of non-Saudi labor to GDP to the percentage decline in GDP as a result of non-Saudi labor's outward remittances.
The percentage contribution of non-Saudi labor to Saudi GDP is equal to the share of non-Saudi labor to total labor in Saudi Arabia times the Saudi GDP whole over GDP, that is,

$$
\frac{\left[\left(\frac{L f}{L t}\right) \times G D P\right]}{G D P} * 100
$$

where, $L f$ is the number of foreign labor in Saudi Arabia and $L t$ stands for the total number of labor in Saudi Arabia.

It should be noted, however, that equation (13), which represents the percentage contribution of non-Saudi laborers in Saudi GDP, is built on the assumption that productivity of non-Saudis is equal to the productivity of Saudis inside Saudi Arabia.

The results of equation (13) are shown as in column (4) of Appendix 3.

The second part required to determine the net contribution of non-Saudi workers' to Saudi GDP is the percentage decline in GDP as a result of non-Saudi labor's outward remittances, that is,

percentage decline in GDP as a

result of non-Saudi labor's outward $=\left[\frac{G D P *}{G D P}\right] * 100$ remittances

The results of equation (14) for the entire study period are shown in column (2) of Appendix 3.

Finally, the difference between the percentage contribution of non-Saudi workers to GDP and the percentage decline in GDP as a result of outward remittances shows whether the positive effect of their contribution to GDP (P) outweighs the negative effect of their outward remittances $(\mathrm{N})$. If $\mathrm{E}$ stands for the net effect of foreign labor on GDP, it follows that

$$
\mathrm{E}=\mathrm{P}-\mathrm{N}
$$

The results of equation (15) for the study sample are shown as in column (4) of Appendix 3.

\section{Findings and Concluding Remarks}

The study findings were the outputs of three methods, namely,

(1) Descriptive statistics to examine the effect of non-Saudi workers' outward remittances on the Saudi current account balance (see Section IV);

(2) Regression analysis using ordinary least squares estimates to study the effect of these remittances on GDP components and GDP as a whole (see Sections VI and VII); and

(3) Comparative numerical study between the negative effect of foreign labor's emittances and the positive effect of foreign labor's contribution to GDP (see Section VII).

Accordingly, the study includes mainly the following findings:

First: Although the current account in Saudi Arabia has 
been always in surplus, this surplus would have been increased by an average of $23.5 \%$ had foreign labor's outward remittances had been zero.

Second: The regression results, as shown in Appendix 1, suggest the following:

i. Non-Saudi workers' outward remittances $\left(R_{n}\right)$ have an almost one-to-one negative relationship with household consumption (C), based on consumption regression equation (2), in Saudi Arabia at a $1 \%$ significance level, which is consistent with macroeconomics theory. Equation (7) calculates the predicted decline values of household consumption $\left(C^{*}\right)$; the results are shown in Appendix 2, column 1.

ii. Investment (I) is negatively affected by outward remittances. The coefficient of $R_{n}$ is -1.31 , as shown in Appendix 1, at a 5\% statistical significance level, suggesting that if $\mathrm{R}_{\mathrm{n}}$ increases by $10 \%$, investments in Saudi Arabia will decrease by $13 \%$. This finding is true in the light of the well-known argument of the multiplier effect. The economic logic behind this finding is that income outflow from the labor-hosting country reduces consumption demand in the labor-hosting country. The fall in consumption demand discourages investors, income falls, and again investment decreases such that several rounds will occur and form the so-called multiplier effect in macroeconomics. Based on regression results shown in Appendix 1, equation (8) is applied, producing predicted declines in investments $\left(\mathrm{I}^{*}\right)$ over the study period, as shown in Appendix 2, column 2.

iii. The coefficient of $R_{n}$ in regression equation (4) for government demand is -0.65 at a $5 \%$ significance level, as shown in Appendix 1. This result indicates that a one-dollar increase in non-Saudi workers' outward remittances, ceteris paribus, will reduce government expenditure by 65 cents. The economic sense behind this finding is that when income outflow (in form of outward remittances) occurs, consumption and investment demands fall; production and income then fall, thus reducing government fees and charges, income tax, zakat, government expenditures on infrastructure. But, of course, Government expenditure and revenues depend on a set of other important factors which remarkably outweigh the negative effect of outward remittances on Government expenditures (G). Depending on regression results and by applying equation (9), the predicted declines in government expenditure $\left(\mathrm{G}^{*}\right)$ are shown in column 3 of Appendix 2.

iv. The findings also show a strong negative impact of outward remittances $\left(R_{n}\right)$ on domestic exports $(X)$ of the labor-hosting country (i.e., Saudi Arabia in this study). Appendix 1 shows that the $R_{n}$ coefficient is -5.40 at a 95\% confidence level and that the regression results of equation (5) are robust and reliable. This finding is consistent with macroeconomic theory and the argument of multiplier effects. Obviously, when consumption, investment, and production all fall as a result of outward remittances, export potential of the country will retreat. Based on the regression results of equation (5) and by applying equation (10), the predicted declines in values of exports as a result of outward remittances are shown as in Appendix 2, column 4.

v. The last component in GDP identity is total imports (M). By running the regression for equation (6), the coefficient of outward remittances $\left(R_{n}\right)$ was found to be -1.39 at $5 \%$ statistical significance. This result also suggests a robust and reliable negative impact of outward remittances on import values. The negative effect of outward remittances on imports is twofold: (1) the first channel through which outward remittances affect imports is in investments. As previously explained, outward remittances reduce investment and production. In a developing country with limited production resources (such as Saudi Arabia), most capital and intermediate goods required for the production process are imported, and therefore, when production falls, imports of inputs also fall. (2) Outward remittances negatively affect imports because of their negative effect on consumption. When such consumption is mainly covered by imported final goods (as is the case for final consumption in Saudi Arabia, where more than $93 \%$ of final consumption is imported), then the higher the outward remittances, the lower the imported final consumption goods in Saudi Arabia will be and vice versa. Applying equation (11) to the study period, the predicted declines in values of imports as a result of increasing non-Saudi workers' outward remittances are shown in column 5 of Appendix 2.

Third: The total effect of non-Saudi workers' outward remittances on the Saudi GDP is simply the sum of the five effects on GDP components that have been determined and explained above. Applying equation (12), the total effect (decline) in GDP as a result of non-Saudi workers' outward remittances for the entire study period is shown in Appendix 3, column 1. Obviously, the effect is negative. The justifications and economic interpretations for this decline are explained above using the analysis of the effect of $R_{n}$ on each component of the GDP components, namely, $C^{*}, I^{*}, G^{*}$, $\mathrm{X}^{*}$ and $\mathrm{M}^{*}$.

Fourth: The study also attempted to answer the question, Does the positive effect of non-Saudi workers' contribution to the Saudi GDP outweigh the negative effect of their outward remittances? The method used to answer this question was explained in step $\mathrm{V}$. The results of equation (15) are shown in columns 2, 3, 4, and 5 of Appendix 3. Column 5 of Appendix 3 answers the above question. The answer is yes, 
except for 6 of the 33 years of the study period. These six years were 1990-1996 but excluding 1992. The negative net effect of non-Saudi workers' contribution to Saudi GDP can be attributed to three factors:

(1) It is well-known to all observers and concerned parties that this period started with the First Gulf War 1990/1991. This war created uncertainty about investment projects in Gulf region and hence lower growth rates;

(2) The economic sluggishness of 1993-1995 in Saudi Arabia and negative growth rates in 1996; and

(3) The above two factors were associated with relatively high outward remittances by non-Saudi workers because of uncertainty about the political and economic stability of the region and hence uncertainty about expatriates' job stability.

Fifth: To avoid the econometric problems of missing variables or misspecification problems (Granger, 1981), the regression system used in the study analysis adjusts/controls for the initial levels of each variable inserted into regression equations and for real oil prices, as the Saudi Arabian economy is oil-driven. Therefore, the regression analysis estimates the effect of these adjusted-for variables. The regression results show that oil prices as well as initial levels of each GDP component have direct, positive, and statistically significant impacts on every corresponding GDP component.

To sum up, the total productivity of non-Saudis significantly outweighs the negative impact of outward workers' remittances. In addition, non-Saudis positively contribute to consumption demand in Saudi Arabia. The estimation of non-Saudis' consumption inside Saudi Arabia as a share of their average income is roughly $65 \%$. The future research, however, should empirically estimate the negative consequences of brain drain on workers' home countries.

\section{Appendix 1}

\section{Regression Results}

The following table shows the effect of non-Saudi workers' outward remittances on household consumption demand, investment demand, government expenditures and external demand.

\begin{tabular}{|c|c|c|c|c|c|c|}
\hline \multirow{2}{*}{ Dependent Variables: } & \multicolumn{4}{|c|}{ Coefficients of Explanatory Variables: } & \multirow{2}{*}{$\mathrm{R}^{2}$} & \multirow{2}{*}{$\begin{array}{l}\mathrm{DW} \\
\text { statistic }\end{array}$} \\
\hline & Constant & $\begin{array}{l}\text { Lagged levels of dependent } \\
\text { variables }\end{array}$ & $R_{n t}$ & $O_{p t}$ & & \\
\hline$C_{t}$ & $\begin{array}{l}-10,660.2 \\
(-4.99)^{* * *}\end{array}$ & $\begin{array}{l}\mathrm{C}_{\mathrm{t}-1}: 0.87 \\
(11.72)^{* * *}\end{array}$ & $\begin{array}{l}-1.05 \\
(-3.10)^{* * *}\end{array}$ & $\begin{array}{l}245.46 \\
(4.23)^{* * *}\end{array}$ & 0.99 & 1.4 \\
\hline$I_{t}$ & $\begin{array}{l}-18435.13 \\
(-2.26)^{* *}\end{array}$ & $\begin{array}{l}\mathrm{I}_{\mathrm{t}-1}: 0.82 \\
(6.22)^{* * *}\end{array}$ & $\begin{array}{l}-1.31 \\
(-2.2)^{* *}\end{array}$ & $\begin{array}{l}314.50 \\
(2.02)^{* *}\end{array}$ & 0.98 & 1.5 \\
\hline$G_{t}$ & $\begin{array}{l}-8863.40 \\
(-3.67)^{* * *}\end{array}$ & $\begin{array}{l}\mathrm{G}_{\mathrm{t}-1}: 0.92 \\
(9.53)^{* * *}\end{array}$ & $\begin{array}{l}-0.65 \\
(-2.18)^{* *}\end{array}$ & $\begin{array}{l}169.00 \\
(2.67)^{* *}\end{array}$ & 0.98 & 1.3 \\
\hline$X_{t}$ & $\begin{array}{l}-76951.1 \\
(-3.17)^{* * *}\end{array}$ & $\begin{array}{l}\mathrm{Xn}_{\mathrm{t}-1}: 0.45 \\
(\mathbf{2 . 6 2})^{* *}\end{array}$ & $\begin{array}{l}-\mathbf{5 . 4 0} \\
(-3.27)^{* * *}\end{array}$ & $\begin{array}{l}\mathbf{1 5 0 0 . 1} \\
(3.21)^{* * *}\end{array}$ & 0.92 & 1.4 \\
\hline$M_{t}$ & $\begin{array}{l}-19567.44 \\
(-2.69)^{* *}\end{array}$ & $\begin{array}{l}\mathrm{M}_{\mathrm{t}-1}: 0.78 \\
(6.42)^{* * *}\end{array}$ & $\begin{array}{c}-1.39 \\
(-2.32)^{* *}\end{array}$ & $\begin{array}{l}457.62 \\
(2.82)^{* *}\end{array}$ & 0.92 & 1.1 \\
\hline
\end{tabular}

Source: Author's estimations.

Note: * denotes that the coefficient is significant at $90 \%$ confidence level; ** reflects a $95 \%$ confidence level; *** indicates the coefficient is significant at $99 \%$ confidence level. 


\section{Appendix 2}

\section{Estimated Decline in GDP Components}

The table below shows the estimated decline in GDP components as a result of non-Saudi workers' outward remittances:

\begin{tabular}{|c|c|c|c|c|c|}
\hline Year & $\begin{array}{l}\text { (1) } \\
\text { C }^{*}\end{array}$ & $\begin{array}{l}\text { (2) } \\
\text { I* }^{*}\end{array}$ & $\begin{array}{l}\text { (3) } \\
\mathrm{G}^{*}\end{array}$ & $\begin{array}{l}(4) \\
X^{*}\end{array}$ & $\begin{array}{l}\text { (5) } \\
\mathrm{M}^{*}\end{array}$ \\
\hline 1981 & -5626.2 & -7022.1 & -3487.0 & -28885.1 & -7417.8 \\
\hline 1982 & -5624.9 & -7020.4 & -3486.2 & -28878.5 & -7416.1 \\
\hline 1983 & -5508.5 & -6875.2 & -3414.0 & -28281.0 & -7262.7 \\
\hline 1984 & -5558.8 & -6938.0 & -3445.2 & -28539.2 & -7329.0 \\
\hline 1985 & -5468.9 & -6825.7 & -3389.5 & -28077.6 & -7210.4 \\
\hline 1986 & -5049.6 & -6302.4 & -3129.6 & -25924.8 & -6657.6 \\
\hline 1987 & -5184.3 & -6470.5 & -3213.1 & -26616.1 & -6835.1 \\
\hline 1988 & -6839.4 & -8536.3 & -4238.9 & -35113.7 & -9017.3 \\
\hline 1989 & -8974.3 & -11200.8 & -5562.0 & -46074.1 & -11832.0 \\
\hline 1990 & -11804.8 & -14733.6 & -7316.3 & -60606.4 & -15564.0 \\
\hline 1991 & -14441.9 & -18024.9 & -8950.7 & -74144.9 & -19040.7 \\
\hline 1992 & -14074.9 & -17566.9 & -8723.2 & -72261.1 & -18557.0 \\
\hline 1993 & -16512.2 & -20608.8 & -10233.8 & -84774.1 & -21770.4 \\
\hline 1994 & -19017.9 & -23736.2 & -11786.8 & -97638.6 & -25074.0 \\
\hline 1995 & -17456.7 & -21787.7 & -10819.2 & -89623.5 & -23015.7 \\
\hline 1996 & -16298.1 & -20341.7 & -10101.1 & -83675.2 & -21488.1 \\
\hline 1997 & -15795.1 & -19713.9 & -9789.4 & -81092.8 & -20825.0 \\
\hline 1998 & -15710.7 & -19608.5 & -9737.1 & -80659.3 & -20713.6 \\
\hline 1999 & -14684.0 & -18327.0 & -9100.7 & -75387.9 & -19359.9 \\
\hline 2000 & -16190.4 & -20207.2 & -10034.4 & -83122.1 & -21346.1 \\
\hline 2001 & -15906.0 & -19852.2 & -9858.1 & -81661.7 & -20971.1 \\
\hline 2002 & -16678.0 & -20815.8 & -10336.5 & -85625.3 & -21988.9 \\
\hline 2003 & -15552.0 & -19410.4 & -9638.7 & -79844.5 & -20504.4 \\
\hline 2004 & -14259.9 & -17797.8 & -8837.9 & -73210.9 & -18800.9 \\
\hline 2005 & -14960.1 & -18671.7 & -9271.9 & -76805.8 & -19724.1 \\
\hline 2006 & -16683.0 & -20822.1 & -10339.7 & -85651.2 & -21995.6 \\
\hline 2007 & -17171.8 & -21432.1 & -10642.6 & -88160.6 & -22640.0 \\
\hline 2008 & -22596.9 & -28203.2 & -14004.9 & -116013.3 & -29792.7 \\
\hline 2009 & -27620.6 & -34473.3 & -17118.5 & -141805.1 & -36416.1 \\
\hline 2010 & -28227.8 & -35231.1 & -17494.8 & -144922.5 & -37216.7 \\
\hline 2011 & -29699.2 & -37067.6 & -18406.7 & -152476.7 & -39156.7 \\
\hline 2012 & -30767.5 & -38400.9 & -19068.8 & -157961.2 & -40565.1 \\
\hline 2013 & -36520.6 & -45581.3 & -22634.4 & -187497.9 & -48150.3 \\
\hline
\end{tabular}

Source: Researcher's calculations based on equations (7), (8), (9), (10), and (11). 


\section{Appendix 3}

\section{Contribution to GDP vs. Decline in GDP}

The table below shows results of calculations performed to determent whether non-Saudi labor contributions to GDP outweigh the decline in GDP as a result of non-Saudi outward workers' remittances.

\begin{tabular}{|c|c|c|c|c|c|}
\hline Year & $\begin{array}{c}(1) \\
\text { GDP* }\end{array}$ & $\begin{array}{l}(2) \\
\text { Percent Decline } \\
\text { in GDP }\end{array}$ & $\begin{array}{c}\text { (3) } \\
\text { Non-Saudis' } \\
\text { Contribution to GDP }\end{array}$ & $\begin{array}{l}\text { (4) } \\
\text { Foreign Labor's Percentage } \\
\text { Contribution to GDP }\end{array}$ & $\begin{array}{l}\text { (5) } \\
\text { Foreign Labor Net } \\
\text { Effect on GDP }\end{array}$ \\
\hline 1981 & -37602.5 & -20.4 & 125050.2 & 67.9 & 47.5 \\
\hline 1982 & -37593.9 & -24.5 & 140061.4 & 91.4 & 66.9 \\
\hline 1983 & -36816.1 & -28.5 & 116462.6 & 90.2 & 61.7 \\
\hline 1984 & -37152.2 & -31.1 & 98177.3 & 82.1 & 51.0 \\
\hline 1985 & -36551.3 & -35.2 & 90919.8 & 87.5 & 52.3 \\
\hline 1986 & -33748.8 & -38.8 & 78959.4 & 90.9 & 52.0 \\
\hline 1987 & -34648.8 & -40.5 & 66033.1 & 77.2 & 36.7 \\
\hline 1988 & -45710.9 & -51.9 & 65042.0 & 73.8 & 21.9 \\
\hline 1989 & -59979.1 & -63.0 & 66985.2 & 70.3 & 7.4 \\
\hline 1990 & -78897.2 & -67.7 & 72365.2 & 62.1 & -5.6 \\
\hline 1991 & -96521.6 & -73.6 & 88633.0 & 67.6 & -6.0 \\
\hline 1992 & -94069.2 & -69.1 & 99682.2 & 73.2 & 4.1 \\
\hline 1993 & -110358.6 & -83.6 & 103453.0 & 78.4 & -5.2 \\
\hline 1994 & -127105.5 & -94.8 & 100301.2 & 74.8 & -20.0 \\
\hline 1995 & -116671.5 & -82.0 & 101952.5 & 71.7 & -10.3 \\
\hline 1996 & -108928.0 & -69.1 & 108123.5 & 68.6 & -0.5 \\
\hline 1997 & -105566.2 & -64.1 & 119724.9 & 72.7 & 8.6 \\
\hline 1998 & -105001.9 & -72.0 & 125228.1 & 85.9 & 13.9 \\
\hline 1999 & -98139.6 & -61.0 & 110787.3 & 68.8 & 7.9 \\
\hline 2000 & -108208.0 & -57.4 & 122327.4 & 64.9 & 7.5 \\
\hline 2001 & -106306.8 & -58.1 & 143215.8 & 78.3 & 20.2 \\
\hline 2002 & -111466.7 & -59.1 & 139089.3 & 73.8 & 14.6 \\
\hline 2003 & -103941.2 & -48.4 & 143298.9 & 66.8 & 18.3 \\
\hline 2004 & -95305.7 & -36.8 & 163075.3 & 63.0 & 26.2 \\
\hline 2005 & -99985.5 & -30.4 & 196644.0 & 59.9 & 29.4 \\
\hline 2006 & -111500.4 & -29.6 & 249630.4 & 66.2 & 36.6 \\
\hline 2007 & -114767.1 & -27.6 & 286444.1 & 68.9 & 41.3 \\
\hline 2008 & -151025.7 & -29.1 & 316133.0 & 60.8 & 31.8 \\
\hline 2009 & -184601.2 & -43.0 & 395045.6 & 92.1 & 49.0 \\
\hline 2010 & -188659.5 & -35.8 & 326114.4 & 61.9 & 26.1 \\
\hline 2011 & -198493.5 & -29.6 & 400376.7 & 59.8 & 30.2 \\
\hline 2012 & -205633.2 & -28.0 & 508825.1 & 69.3 & 41.3 \\
\hline 2013 & -244084.1 & -32.6 & 557806.4 & 74.5 & 41.9 \\
\hline
\end{tabular}

Source: Researcher's calculations based on equations (12), (13), (14), and (15). 


\section{REFERENCES}

[1] Brown RPC. Estimating remittance functions for Pacific Island migrants. World Development 1997; 25(4).

[2] Athamneh AB. The effect of labor migration on economic growth: The case of Jordan(1970-2001) . Mu'tah Lil-Buhuth Wad-Dirasat 2004; 19(5).

[3] Talafha H. The role of guest workers in the economy of Jordan. Abhath Al-Yarmouk-Humanities and Social Sciences Series 1989; 5(1).

[4] Baker M, Benjamin D. The performance of immigrants in the Canadian labor market. Journal of Labor Economics 1994; 12(3).

[5] Andersen TM, Herbertsson TT. IZA Discussion Paper No.817.. Measuring globalization. IZA Discussion Paper 2003; No.817.

[6] Al Akayleh F. Labor migration, workers' remittances, and economic activity: New instrumental variables for the effect of remittances. Journal of Social Sciences 2011; 28(3).

[7] Agarwal R, Horowitz AW . Are international remittances altruism or insurance? Evidence from Guyana using multiple-migrant households. World Development 2002; 30(11).

[8] Barham B, Boucher S. Migration, remittances, and inequality: Estimating the net effects of migration on income distribution. Journal of Development Economics 1998; 55(3).

[9] Friedberg RM. You can't take it with you? Immigrant assimilation and the probability of human capital. Journal of Labor Economics 2002; 18(2).

[10] Hemmi N. Brain drain and economic growth theory and evidence: A comment. Journal of Development Economics $2005 ; 77(3)$.

[11] Stiglitz JE. Making Globalization Work: The Next Steps to
Global Justice, 1st ed. London: Penguin; 2006.

[12] Saudi Arabian Monetary Agency. Economic Reports. Saudi Arabia: Saudi Arabian Monetary Agency; 2015. http://www.sama.gov.sa/enus/EconomicReports/Pages/defau lt.aspx (accessed 20 May 2015).

[13] Taher FB. Determinants of private saving in Saudi Arabia. King Faisal University's Scientific Journal 2001; 2(1).

[14] Bratsberg B Jr, Ragan, JF, Nasir ZM. The effect of naturalization on wage growth: A panel study of young male immigrants. Journal of Labor Economics 2002; 20(3).

[15] Duraisamy P. Migration, remittances and family ties in urban informal sector. Indian Journal of Labor Economics 2000; 48(1).

[16] Fargues P. Arab migration to Europe: Trends and policies. International Migration Review 2004; 38(4).

[17] Saudi Arabian Central Department of Statistics and Information. Economic Statistics Database. Saudi Arabia : Saudi Arabian Central Department of Statistics and Information; 2015. http://www.cdsi.gov.sa (accessed 20 July 2015).

[18] Ministry of Civil Service . Annual Report, 3rd ed. Saudi Arabia: Ministry of Civil Service ; 2015.

[19] Google Books The report: Saudi Arabia 2013. (accessed 10 July 2015).. The report: Saudi Arabia 2013. Saudi Arabia: Saudi Arabian Monetary Agency; 2013. http://www.sama.go v.sa/enus/EconomicReports/Pages/default.aspx (accessed 10 July 2015).

[20] United Nations Conference on Trade and Development (UNCTAD). UNCTAD Handbook of Statistics. Saudi Arabia : Saudi Arabian Monetary Agency; 2015. www.unctad.org (accessed 10 June 2015).

[21] Box GEP, Jenkins GM, Reinsel GC. Time Series Analysis: Forecasting and Control, 3rd ed. Singapore: Pearson Education; 2004.

[22] Granger CWJ. Some properties of time series data and their use in econometric model specification. Journal of Econometrics 1981; 16(1). 